ISSN 1392-3196 / e-ISSN 2335-8947

Zemdirbyste-Agriculture, vol. 104, No. 2 (2017), p. 139-146

DOI 10.13080/z-a.2017.104.018

\title{
The influence of $\beta$-alanine derivative products on spring oilseed rape yield and oil quality
}

\author{
Ramūnė KOLOSEJ ${ }^{1}$, Ilona JONUŠKIENE ${ }^{1}$, Petras Rimantas VENSKUTONIS ${ }^{1}$,

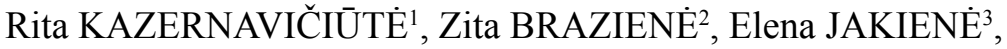 \\ Kotryna KVEDERAVIČIŪTE ${ }^{4}$, Arvydas KANOPKA ${ }^{4}$, Laurynas VILYS ${ }^{4}$, \\ Vytautas MICKEVIČIUS ${ }^{1}$ \\ ${ }^{1}$ Kaunas University of Technology \\ Radvilènu 19, Kaunas, Lithuania \\ E-mail: ramuneg2004@yahoo.com \\ ${ }^{2}$ Rumokai Experimental Station, Lithuanian Research Centre for Agriculture and Forestry \\ Klausučiai, Vilkaviškis distr., Lithuania \\ ${ }^{3}$ Institute of Agricultural and Food Sciences, Aleksandras Stulginskis University \\ Studentų 11, Akademija, Kaunas distr., Lithuania \\ ${ }^{4}$ Institute of Biotechnology, Vilnius University \\ V. Graičiūno 8, Vilnius, Lithuania
}

\begin{abstract}
In 2012-2014, field experiments were conducted at Rumokai Experimental Station of the Lithuanian Research Centre for Agriculture and Forestry with a view to estimating the effects of different concentrations of $N$-phenyl$N$-(5-oxo-4,5-dihydro-1,3-thiazol-2-yl)- $\beta$-alanine sodium salt (NPNDT) on spring oilseed rape.

Field experiments showed that $125 \mathrm{mg} \mathrm{l}^{-1}$ NPNDT solution had the greatest effect on plant growth. In this treatment, the number of secondary branches increased by $54 \%$, the rapeseed yield by $23 \%$ compared with the control treatment. The highest seed number per silique $(24.5$ seeds, or $7.5 \%$ higher than in the control) was determined in the treatment where oilseed rape seedlings had been sprayed with $75 \mathrm{mg} \mathrm{l}^{-1}$ NPNDT solution. The highest oil and protein contents in rapeseed were determined in the $75 \mathrm{mg} \mathrm{l}^{-1}$ NPNDT treatment. Compared with the control, a statistically significant increase in rapeseed oil amounted to $137.9 \mathrm{~kg} \mathrm{ha}^{-1}$ or $17 \%$ and protein content to $6.2 \mathrm{~g}$ $100 \mathrm{~g}^{-1}$ or $31 \%$. The increase in rapeseed yield was statistically significant $(P<0.05)$ in all treatments. The increase of oil content was positively correlated with the seed yield increase $(P<0.05)$ when oilseed rape was sprayed with the $50 \mathrm{mg} \mathrm{l}^{-1}$ concentration of NPNDT solution.

The NPNDT had a positive effect on oil quality. It increased protein and flavonoid contents, reduced ash content in rapeseed and increased DPPH radical scavenging in rapeseed extract.
\end{abstract}

Key words: $\beta$-alanine derivative, Brassica napus, oil, RAPD, seed yield.

\section{Introduction}

Oilseed rape (Brassica napus L.) is one of the most important oilseeds with the highest content (30-45\%) of oil (Baux et al., 2008). Rapeseed oil, free of anti-nutritional substances, has a higher dietary value than many other vegetable oils due to the low content of saturated fatty acids, high oleic acid content, favourable ratio of polyunsatured linoleic and linolenic acids, as well as presence of sterols and fat-soluble vitamins (Cegielska-Taras, Pniewski, 2011). In addition, the ratio of omega-6:omega-3 fatty acids in rapeseed oil is $2: 1$, which is beneficial for human health, as possessing anti- inflammatory effects and protecting against heart diseases (Ion et al., 2010).

The plant growth and productivity are affected by various abiotic factors such as heat, salinity, cold, etc. (Pietryczuk et al., 2014). Oilseed rape crop growth and yield quality can be enhanced by increasing plant nitrogen uptake through the use of fertilizers, spray-application of growth regulators or cobalt sulphate during growth $(\mathrm{Gad}$, 2010; Ullah et al., 2012). Plant growth regulators are important compounds for the rapeseed yield and quality (Matysiak, Kaczmarek, 2013; Huberman et al., 2014).

Please use the following format when citing the article:

Kolosej R., Jonuškienė I., Venskutonis P. R., Kazernavičiūtė R., Brazienė Z., Jakienė E., Kvederavičiūtė K., Kanopka A., Vilys L., Mickevičius V. 2017. The influence of $\beta$-alanine derivative products on spring oilseed rape yield and oil quality. ZemdirbysteAgriculture, 104 (2): 139-146 DOI 10.13080/z-a.2017.104.018 
The number of pods per plant, the number of seeds per pod as well as seed weight, as factors affecting both plant nutrition and hormones, influence the yield and quality of rapeseed. The number of seeds per pod may be increased by the growth regulators such as indole-3acetic acid, whereas the number of pods per plant was increased by using 6-benzylaminopurine (Mohammadi et al., 2014).

Vegetable oils, depending on the content of unsaturated fatty acids, are sensitive to oxidation which finally renders the oil unusable for consumption. As a result, antioxidants are frequently added to inhibit lipid oxidation; however, the plants, including oilseed rape, biosynthesize numerous secondary metabolites, which may act as antioxidants or preservatives. These compounds may be lipophilic (tocols) and hydrophilic (ascorbic acid, flavonoids, phenolic acids). They may act both as primary (radical scavenging via single electron/ hydrogen atom transfer) and secondary (metal catalyst chelators, single oxygen scavengers) antioxidants (Akoh, Min, 2002).

Flavonoids belong to a group of phenolic compounds and in food plants are responsible for biological factors, such as the defence system against viruses, bacteria, fungi, insects, protection against biotic and abiotic stresses, and can control plant hormones (Crozier et al., 2009; Pascual-Teresa et al., 2010; Amalesh et al., 2011; Cartea et al., 2011). Flavonoids absorb UV rays which are harmful to plant cells (Amalesh et al., 2011).

$\beta$-alanine is a non-protein amino acid found in all organisms (White et al., 2001); in plants it was found increasing in response to environmental stress. Various $\beta$-amino acids are present in the formula of different natural products, such as peptides, cyclopeptides, depsipeptides, glycopeptides, alkaloids, or terpenoids (Patočka, 2010). $\beta$-amino acids are currently of growing interest not only because of their roles, but also because of their use in the synthesis of peptide mimetics and of certain quite biologically active substances. Natural derivatives of $\beta$-amino acids are often characterized by potent pharmacological and toxicological activities crucially based on their $\beta$-amino acid substructures. The most important $\beta$-amino acids are $\beta$-alanine, $\beta$-leucine, $\beta$-arganine, $\beta$-glutamate, $\beta$-phenylalanine and $\beta$-tyrosine (Patočka, 2011).

The random amplified polymorphic DNA (RAPD) has been used to study the extent of genetic variation among the diverse groups of important crop species in the genus Brassica. The value of RAPD analysis for the efficient germplasm management in plants is already known. The technique is quick, easy and requires less time compared to other techniques. RAPD method detects nucleotide sequence polymorphisms using a single primer of arbitrary nucleotide sequence (Abdelmigid, 2012).

The present investigation aimed to determine the effect of $N$-phenyl- $N$-(4,5-dihydro-4-oxo-2-thiazolyl)$\beta$-alanine sodium salt on spring oilseed rape (Brassica napus L.) seed yield and quality.

\section{Materials and methods}

Field experiments on the influence of $N$-phenyl$N$-(4,5-dihydro-4-oxo-2-thiazolyl)- $\beta$-alanine sodium salt (NPNDT) on spring oilseed rape (Brassica napus L.) were carried out in 2012-2013 at the Rumokai Experimental
Station of the Lithuanian Research Centre for Agriculture and Forestry. The study involved the spring rape variety 'SW Landmark'.

Oilseed rape plants were sprayed with the compound solutions (concentrations 25-150 mg L-1) before the flowering stage (BBCH 50). The soil of the experimental field is Calcari-Epihypogleyic Luvisol ( $\mathrm{LVg}$ $p-w-c c)$ with the following characteristics: $\mathrm{pH}_{\mathrm{KCl}}$ 6.7, $1.82 \%$ humus, $0.12 \% \mathrm{~N}_{\text {total }}, 308 \mathrm{mg} \mathrm{kg}^{-1}$ mobile $\mathrm{P}_{2} \mathrm{O}_{5}$ and $296 \mathrm{mg} \mathrm{kg}^{-1}$ mobile $\mathrm{K}_{2} \mathrm{O}$. Barley was the preceding crop.

The plot size was $2.7 \times 11 \mathrm{~m}$. The harvested plot size was $2.2 \times 10 \mathrm{~m}$. The experiments with oilseed rape were performed in April-August. Samples for counts of branches and siliques per plant and seed number per silique were taken from each plot before harvesting in four places $0.25 \mathrm{~m}^{2}$ per plot. During harvesting the rapeseed yield collected from each plot was weighed separately, rapeseed moisture content was determined and seed samples for determination of quality parameters were collected. The seed yield of spring oilseed rape was corrected to $8.5 \%$ standard moisture. The protein content in rapeseed was measured by the Bradford (1976) method. Rapeseed ash content was determined by combustion at $500^{\circ} \mathrm{C}$ for $3 \mathrm{~h}$.

The total amount of flavonoids was determined according to $\mathrm{AlCl}_{3}$ colorimetric method (Singleton et al., 1999). Two grams of shredded plant material were diluted with $20 \mathrm{~mL}$ acetone and $2 \mathrm{~mL}$ of $28 \%$ hydrochloric acid and heated under reflux for $30 \mathrm{~min}$ in a round-bottom flask. After cooling, the hydrolyzate was filtered into a $100 \mathrm{~mL}$ volumetric flask, the remaining slurry was returned to the round-bottom flask and after adding $20 \mathrm{~mL}$ acetone was heated under reflux for $10 \mathrm{~min}$. After cooling, the hydrolyzate was filtered into the same volumetric flask. The content of the flask was diluted with acetone up to $100 \mathrm{~mL}$ volume. Twenty $\mathrm{mL}$ of obtained solution were diluted with $20 \mathrm{~mL}$ water and extracted with ethyl acetate four times: $1 \times 15$ and $3 \times$ $10 \mathrm{ml}$. The combined upper fractions were washed with $40 \mathrm{~mL}$ water, filtered into $50 \mathrm{~mL}$ volumetric flask and the filtrate was diluted with ethyl acetate up to $50 \mathrm{ml}$ volume. The test solution was prepared by adding $2 \mathrm{ml}$ of $\mathrm{AlCl}_{3}$ solution $\left(20 \mathrm{~g} \mathrm{l}^{-1}\right)$ to $10 \mathrm{ml}$ of the main solution and filling the flask up to $25 \mathrm{ml}$ volume by solution of acetic acid and methanol (1:19). The reference solution was prepared by adding the same acetic acid - methanol $(1: 19)$ solution to $10 \mathrm{ml}$ of the main solution up to $25 \mathrm{ml}$ volume. After $30 \mathrm{~min}$, the absorbance was measured at $415 \mathrm{~nm}$ in a spectrophotometer UV-200-RS using the reference solution. The amount of flavonoids $(\mathrm{x}, \%)$ was calculated as follows: $\mathrm{x}=(\mathrm{A} \times \mathrm{k}) / \mathrm{m}$, where $\mathrm{A}$ is the absorbance of the reference solution, $\mathrm{k}-\mathrm{a}$ correction coefficient for hyperozide $(\mathrm{k}=1.25)$, and $\mathrm{m}-$ mass of the plant $(\mathrm{g})$.

DPPH• (1,1-diphenyl-2-picrylhydrazyl) scavenging assay. Free radical scavenging capacity (RSC) of compounds was measured by DPPH using the widely used method (Madhu et al., 2011). Briefly, $1 \mathrm{~mL}$ of $1 \mathrm{mM}$ DPPH solution in ethanol was added to the solutions of the tested compounds ( $1 \mathrm{mg} \mathrm{ml}^{-1}$ of dimethyl sulfoxide). The mixture was shaken vigorously and allowed to stand at room temperature for $20 \mathrm{~min}$. Afterwards, the absorbance was measured at $517 \mathrm{~nm}$ in 
a spectrophotometer UV-200-RS (MRC Ltd., Israel). The RSC values were calculated according to the following equation: $\operatorname{RSC}(\%)=\left(A_{0}-A_{1} / A_{0}\right) \times 100$, where $A_{0}$ is the absorbance of the control reaction, and $A_{1}-$ the absorbance in the presence of the samples.

The oil content in rapeseed was measured by extraction with hexane for 3 hours in an apparatus Soxhlet (Behr Labor-Technik, Germany). Fatty acid composition was analyzed with a gas chromatograph HRGC 5300 Mega Series (Carlo Erba Strumentazione, Italy). The oil yield was determined from seed yield and oil content.

Oilseed rape plants sprayed with $125 \mathrm{mg} \mathrm{l}^{-1}$ concentration of NPNDT were used for the random amplified polymorphic DNA (RAPD) analysis. Plant samples were taken at growth stage 64-69 according to the BBCH scale. Plant genomic DNA (gDNA) was extracted from the frozen leaf samples as described elsewhere (Edwards et al., 1991). Approximately $0.5 \mathrm{~cm}^{2}$ plant tissue was ground in a microcentrifuge tube with $400 \mu \mathrm{l}$ of extraction buffer $(200 \mathrm{mM}$ Tris- $\mathrm{HCl} \mathrm{pH} 7.5$, $250 \mathrm{mM} \mathrm{NaCl}, 25 \mathrm{mM}$ EDTA, 0.5\% w/v SDS), vortexed for $5 \mathrm{~s}$ and centrifuged at $16100 \mathrm{rpm}$ for $1.5 \mathrm{~min} .300 \mu \mathrm{l}$ of supernatant was mixed with $300 \mu \mathrm{l}$ of isopropanol to precipitate gDNA. gDNA was pelleted by centrifugation at $16100 \mathrm{rpm}$ for $5 \mathrm{~min}$ and later dissolved in $100 \mu \mathrm{TE}$ buffer (10 mM Tris-HCl pH 8.0, 1 mM EDTA pH 8.0).

RAPD was carried out using Taq polymerase in $25 \mu \mathrm{l}$ reaction mixture containing $2 \mu \mathrm{l}$ of gDNA extract, $1 \times$ Taq polymerase buffer (ThermoFisher Scientific, Lithuania), $2.5 \mathrm{mM} \mathrm{MgCl}_{2} 0.24 \mu \mathrm{M}$ primer, $0.2 \mu \mathrm{M}$ dNTPs (Table 1). Polymerase chain reaction (PCR) settings (annealing temperature) were set by analysis of gradient PCR results. Extension was carried out for $1 \mathrm{~min}$ and 35 cycles were done.

For the separation of amplified products, agarose gel electrophoresis was performed using $1 \%$ agarose gels.
Table 1. Sequences of primers used for analysis, total number of bands counted and DNA fragment size (Nanodiagnostika, Lithuania)

\begin{tabular}{cccc}
\hline $\begin{array}{c}\text { Primer } \\
\text { number }\end{array}$ & Primer sequence & $\begin{array}{c}\text { Total } \\
\text { number } \\
\text { of bands }\end{array}$ & $\begin{array}{c}\text { Fragment } \\
\text { size range } \\
\text { bp }\end{array}$ \\
\hline P-01 & 5'-GGGTAACGCC-3' & 8 & $250-1200$ \\
P-02 & 5'-CAATCGCCGT-3' & 4 & $300-900$ \\
P-03 & 5'-AATCGGGCTG-3' & 4 & $600-1200$ \\
\hline
\end{tabular}

Amplified DNA was stained using ethidium bromide and visualized under UV light. DNA amplification was carried out in PCR tubes; the total reaction volume was $25 \mu \mathrm{l}$. DNA amplification was performed using a thermocycler Veriti ${ }^{\circledR}$ 96-Well Thermal Cycler (Applied Biosystems, USA) programmed to 1 cycle at $94^{\circ} \mathrm{C}$ for $5 \mathrm{~min}$, following 35 cycles at $94^{\circ} \mathrm{C}$ for $30 \mathrm{~s}$, at $42-44^{\circ} \mathrm{C}$ for $1 \mathrm{~min}$, at $72^{\circ} \mathrm{C}$ for $1 \mathrm{~min}$, final extension at $72^{\circ} \mathrm{C}$ for $1 \mathrm{~min}$, and kept at $4^{\circ} \mathrm{C}$ (Jodinskienè et al., 2008). After amplification, PCR products were separated by electrophoresis in $1 \%$ agarose gel. The agarose gel was stained with ethidium bromide and photographed under the UV light using the pro gel documentation system BioImaging MiniBis (ThermoFisher Scientific, Lithuania).

Statistical analysis. For the comparison of the obtained means, a two-tailed Welch's $t$-test intended for use with samples having possibly unequal variances was performed in the Microsoft Excel 2010 (Ziauka et al., 2013).

\section{Results and discussion}

Before harvesting, biometric properties of oilseed rape plants were determined (Table 2). In all three experimental years, the oilseed rape plant height varied slightly in comparison with the control treatment. In the

Table 2. Effect of different NPNDT concentrations on the biometric properties of oilseed rape plants

\begin{tabular}{|c|c|c|c|c|c|c|c|c|}
\hline \multirow{2}{*}{$\begin{array}{l}\text { Biometric } \\
\text { properties }\end{array}$} & \multirow[t]{2}{*}{ Year } & \multicolumn{7}{|c|}{$\begin{array}{l}\text { NPNDT concentration } \\
\mathrm{mg} \mathrm{l}^{-1}\end{array}$} \\
\hline & & rol) & 25 & 50 & 75 & 100 & 125 & 150 \\
\hline \multirow{4}{*}{$\begin{array}{l}\text { Plant height } \\
\mathrm{cm}\end{array}$} & 2012 & $130.7 \pm 0.1$ & $133.5^{*} \pm 0.1$ & $129.5 \pm 0.2$ & $130.9 \pm 0.2$ & $127.6 \pm 0.3$ & $124.4 \pm 0.2$ & $30.9 \pm 0.3$ \\
\hline & 2013 & 117.0 & - & $116.1 \pm 0.2$ & $116.5 \pm 0.5$ & $117.0 \pm 0.3$ & $115.4 \pm 0.3$ & - \\
\hline & 2014 & $120.3 \pm 0.1$ & - & $123.5 \pm 0.5$ & $127.0^{*} \pm 0.2$ & $124.3 \pm 0.2$ & $125.5 \pm 0.3$ & - \\
\hline & average & 121.7 & $133.5 \pm 0.1$ & $122.2 \pm 0.6$ & $124.1 * \pm 0.7$ & $122.4 \pm 0.5$ & $121.4 \pm 0.6$ & $130.9 \pm 0.3$ \\
\hline \multirow{4}{*}{$\begin{array}{c}\text { Number } \\
\text { of primary } \\
\text { branches } \\
\text { per plant }\end{array}$} & 2012 & $5.4 \pm 0.02$ & $5.5 \pm 0.0$ & $5.5 \pm 0.03$ & $5.3 \pm 0.02$ & $5.8^{*} \pm 0.02$ & $5.3 \pm 0.01$ & $5.4 \pm 0.02$ \\
\hline & 2013 & & - & $3 \pm 0.02$ & $3.1 \pm 0.02$ & $2.9 \pm 0.04$ & & - \\
\hline & 2014 & & - & $3 \pm 0.07$ & $3.4^{*} \pm 0$ & & & - \\
\hline & average & & $5.5 \pm 0.0$ & $3.6 \pm 0.12$ & $3.8 * \pm$ & $3.4 \pm$ & 3.8 & $5.4 \pm 0.02$ \\
\hline \multirow{4}{*}{$\begin{array}{l}\text { Number of } \\
\text { secondary } \\
\text { branches } \\
\text { per plant }\end{array}$} & 2012 & & $3.7 \pm 0$ & \pm 0.07 & $4.9 \pm$ & 5.0 & & $3.1 \pm 0$ \\
\hline & 2013 & & - & $3.0 \pm 0.03$ & $3.5 \pm$ & $3.1=$ & & - \\
\hline & 2014 & 6.1 & - & $6.7 \pm 0.11$ & $6.8 \pm 0.15$ & $8.1 \pm$ & $8.3^{*} \pm$ & - \\
\hline & average & $3.9=$ & $3.7 \pm 0.05$ & $4.7 \pm 0.18$ & $5.1 \pm 0.18$ & $5.4 \pm$ & $6.0 * \pm$ & $3.1 \pm 0.01$ \\
\hline \multirow{4}{*}{$\begin{array}{l}\text { Number of } \\
\text { siliques } \\
\text { per plant }\end{array}$} & 2012 & $131.8 \pm 0.1$ & $118 \pm 0.6$ & $128.2 \pm 0.3$ & $129.7 \pm 0.6$ & $145.9 * \pm 0.2$ & $141.4 \pm 0.3$ & $131.8 \pm 0.1$ \\
\hline & 2013 & $57.2 \pm 0.3$ & - & $57.2 \pm 0.1$ & $61.1 \pm 0.2$ & $62.4 \pm 0.2$ & $63.6^{*} \pm 0.4$ & - \\
\hline & 2014 & & - & $85.2 \pm 0.9$ & $85.3 \pm 1.0$ & $82.8 \pm 0.4$ & $107.3^{*} \pm 1.4$ & - \\
\hline & average & $83.5=$ & $118 \pm 0.6$ & $85.5 \pm 2.9$ & $87.3 \pm 2.9$ & $90.9 \pm$ & $99.4 * \pm 3.4$ & $131.8 \pm 0.1$ \\
\hline \multirow{4}{*}{$\begin{array}{l}\text { Number of } \\
\text { seeds } \\
\text { per silique }\end{array}$} & 2012 & $19.4 \pm 0.01$ & & $21.3^{*} \pm 0.01$ & $21.1 \pm 0.09$ & $19.8 \pm 0.09$ & $19.6 \pm 0.03$ & $20.2 \pm 0.06$ \\
\hline & 2013 & $24.1 \pm 0.06$ & - & $26.4 \pm 0.08$ & $27.0 \pm 0.10$ & $27.0 * \pm 0.07$ & $26.1 \pm 0.11$ & - \\
\hline & 2014 & $23.8 \pm 0.02$ & - & $24.5 \pm 0.02$ & $24.3 \pm 0.08$ & $24.7 \pm 0.07$ & $25.7^{*} \pm 0.13$ & - \\
\hline & average & $22.8 \pm 0.22$ & $20.1 \pm 0.06$ & $24.4 \pm 0.22$ & $24.5^{*} \pm 0.26$ & $24.3 \pm 0.30$ & $24.3 \pm 0.31$ & $20.2 \pm 0.06$ \\
\hline \multirow{4}{*}{$\begin{array}{l}\text { Silique } \\
\text { length } \\
\mathrm{cm}\end{array}$} & 2012 & $7.4 \pm 0.00$ & $7.4 \pm 0.01$ & $7.9 * \pm 0.05$ & $7.4 \pm 0.01$ & $7.3 \pm 0.03$ & $7.5 \pm 0.01$ & $7.6 \pm 0.01$ \\
\hline & 2013 & $7.3 \pm 0.02$ & - & $7.5^{*} \pm 0.01$ & $7.5 \pm 0.02$ & $7.4 \pm 0.01$ & $7.3 \pm 0.02$ & - \\
\hline & 2014 & $7.8 \pm 0.01$ & - & $8.1 * \pm 0.01$ & $7.8 \pm 0.02$ & $7.9 \pm 0.03$ & $8.1 \pm 0.02$ & - \\
\hline & average & $7.5 \pm 0.03$ & $7.4 \pm 0.01$ & $7.8 * \pm 0.03$ & $7.6 \pm 0.03$ & $7.6 \pm 0.03$ & $7.6 \pm 0.04$ & $7.6 \pm 0.01$ \\
\hline
\end{tabular}

* - the highest positive difference in comparison with the control; values are mean \pm standard deviation (SD), $P<0.05$ 
second year of study, the plants had a lower height.

In the first experimental year, the plant height ranged from 124.4 to $133.5 \mathrm{~cm}$, in the second year - from 115.4 to $117.0 \mathrm{~cm}$ and in the third year - from 120.3 to $127.0 \mathrm{~cm}$. The data averaged over the three experimental years showed that the lowest plant height was determined in the treatments sprayed with $125 \mathrm{mg} \mathrm{l}^{-1}$ of NPNDT solution.

The number of secondary branches per plant is an important biometric parameter. In the first experimental year, this number ranged from 3.1 to 5.4. The highest number of secondary branches was obtained in the treatments sprayed with $125 \mathrm{mg} \mathrm{l}^{-1}$ of NPNDT; it was by $69 \%$ higher than in the control treatment. In the second experimental year, the number of secondary branches was lower than in the first year, but higher than in the control sample. In the third experimental year, this number ranged from 6.1 to 8.3. The highest number of secondary branches was obtained in the treatments sprayed with $125 \mathrm{mg} \mathrm{l}^{-1}$ of NPNDT; it was by $36 \%$ higher than in the control treatment. Summarizing three experimental years, the highest number of secondary branches was obtained in the treatments sprayed with $125 \mathrm{mg} \mathrm{l}^{-1}$ of NPNDT. The average number of secondary branches increased by $54 \%$ compared with the control treatment. The highest number of siliques was obtained in the first experimental year in the $100 \mathrm{mg} \mathrm{l}^{-1}$ and in the second and the third years in the $125 \mathrm{mg} \mathrm{l}^{-1}$ of NPNDT treatments. In the first and the second year, the NPNDT solution increased the number of siliques by $11 \%$ in the third year by $38 \%$ compared with the control treatment. The researchers (Kazlauskiene et al., 2008) studied the influence of physiological analogues of auxin - TA-12 $(2 \mathrm{mM})$ and TA-14 $(4 \mathrm{mM})$ on oilseed rape flowering and reproductive organ formation. It has been found that TA-12 shortens the duration of flowering and increases the number of siliques per plant. Other researchers (Darginavičienè et al., 2011) have shown that the rapeseed cv. 'SW Landmark' sprayed with Ethephon (10 mM) formed more siliques on the primary and secondary branches as compared to the rapeseed hybrid cv. 'Terra'. In the first experimental year, the length of siliques varied from $-1 \%$ to $+6 \%$, in the second year from $0 \%$ to $+3 \%$ and in the third year from $0 \%$ to $+4 \%$ compared ith the control treatment. The longest siliques $(7.8 \mathrm{~cm})$ were produced in the treatment sprayed with $50 \mathrm{mg} \mathrm{l}^{-1}$ of NPNDT.

The NPNDT increased seed number per silique. In the first year, the number of seeds per silique increased by $1-10 \%$, in the second year by $8-12 \%$ and in the third year by $2-8 \%$ compared with the control treatment. The highest number of seeds per pod was obtained in the treatment sprayed with $50 \mathrm{mg} \mathrm{l}^{-1}$ of NPNDT.

A previous study on the influence of N-(4methoxy-2-nitrophenyl)- $\beta$-alanine sodium salt $(380 \mu \mathrm{M})$ on oilseed rape showed, that the number of primary branches varied from $+2 \%$ to $+13 \%$, secondary branches - from $+11 \%$ to $+155 \%$, silique number per plant - from $+3 \%$ to $+75 \%$, seed number per silique - from $+2.5 \%$ to $+5.3 \%$ compared with the control treatment (Žiaukiene et al., 2010).

The application of NPNDT increased the rapeseed yield in the first experimental year from 0.33 to $0.70 \mathrm{tha}^{-1}$, in the second year from 0.22 to $0.46 \mathrm{tha}^{-1}$, and in the third year from 0.10 to $0.30 \mathrm{t} \mathrm{ha}^{-1}$ (Table 3 ). The rapeseed yield ranged from $+19 \%$ to $+40 \%$ compared with the control treatment in the first experimental year, from $+12 \%$ to $+26 \%$ in the second year and from $+4 \%$ to $+9 \%$ in the third year. Average data showed that the highest seed yield was achieved in the treatments sprayed with $125 \mathrm{mg} \mathrm{l}^{-1}$ concentration of NPNDT solution. The increase in rapeseed yield was statistically significant $(P<0.05)$ in all treatments.

The highest 1000 seed weight (4.2 g) was determined in the $25 \mathrm{mg} \mathrm{l}^{-1}$ NPNDT treatment in the first experimental year; it reached $4.0 \mathrm{~g}$ in the $100 \mathrm{mg} \mathrm{l}^{-1}$ NPNDT treatment in the second year and $4.0 \mathrm{~g}$ in the $125 \mathrm{mg} \mathrm{l}^{-1}$ NPNDT treatment in the third year. Our results on the oilseed rape cv. 'SW Landmark' agree with those of Darginavičienè et al. (2011). The studies have shown that the 1000 seed weight of cv. 'SW Landmark' was by about $10 \%$ higher than that of the hybrid cv. 'Terra', but Ethephon $(10 \mathrm{mM})$ increased the weight of cv. 'SW Landmark' only by $3-4 \%$.

In 2012-2014, the oil content in rapeseed varied

Table 3. Effect of different NPNDT concentrations on rapeseed yield

\begin{tabular}{|c|c|c|c|c|c|c|c|c|}
\hline \multirow[t]{2}{*}{ Variable } & \multirow[t]{2}{*}{ Year } & \multicolumn{7}{|c|}{$\begin{array}{l}\text { NPNDT concentration } \\
\mathrm{mg} \mathrm{l}^{-1}\end{array}$} \\
\hline & & 0 (control) & 25 & 50 & 75 & 100 & 125 & 150 \\
\hline \multirow{4}{*}{$\begin{array}{l}\text { Yield } \\
\mathrm{t} \mathrm{ha}^{-1}\end{array}$} & 2012 & $1.74 \pm 0.06$ & $2.07 \pm 0.12$ & $2.21 \pm 0.06$ & $2.11 \pm 0.18$ & $2.20 \pm 0.06$ & $2.41 \pm 0.06$ & $2.44 * \pm 0.12$ \\
\hline & 2013 & $1.79 \pm 0.12$ & - & $2.01 \pm 0.06$ & $2.19 \pm 0.06$ & $2.25^{*} \pm 0.12$ & $2.20 \pm 0.06$ & - \\
\hline & 2014 & $2.3 \pm 0.06$ & - & $2.4 \pm 0.06$ & $2.5 \pm 0.06$ & $2.4 \pm 0.06$ & $2.6 * \pm 0.06$ & - \\
\hline & average & $1.9 \pm 0.18$ & $2.1 \pm 0.12$ & $2.2 \pm 0.12$ & $2.3 \pm 0.18$ & $2.3 \pm 0.12$ & $2.4 * \pm 0.12$ & $2.4 \pm 0.12$ \\
\hline \multirow{4}{*}{$\begin{array}{c}1000 \text { seed } \\
\text { weight } \\
\text { g }\end{array}$} & 2012 & $3.9 \pm 0.04$ & $4.2 * \pm 0.01$ & $4.0 \pm 0.01$ & $3.8 \pm 0.04$ & $4.0 \pm 0$ & $3.9 \pm 0.02$ & $3.9 \pm 0.04$ \\
\hline & 2013 & $3.9 \pm 0.01$ & - & $4.0 \pm 0.04$ & $4.0 \pm 0.01$ & $4.0 * \pm 0.04$ & $4.0 \pm 0.01$ & - \\
\hline & 2014 & $4.0 \pm 0.04$ & - & $4.0 \pm 0.01$ & $4.0 \pm 0.04$ & $4.0 \pm 0.01$ & $4.0 * \pm 0.01$ & - \\
\hline & average & $3.9 \pm 0.01$ & $4.2 \pm 0.01$ & $4.0^{*} \pm 0.01$ & $3.9 \pm 0.04$ & $4.0 \pm 0.01$ & $3.9 \pm 0.04$ & $3.9 \pm 0.04$ \\
\hline \multirow{4}{*}{$\begin{array}{c}\text { Oil } \\
\text { content } \\
\mathrm{kg} \mathrm{t}^{-1}\end{array}$} & 2012 & $329.6 \pm 1.4$ & $388.2 \pm 6.7$ & $372.3 \pm 6.1$ & $458.1^{*} \pm 4.6$ & $412.7 \pm 3.9$ & $386.1 \pm 6.4$ & $406.4 \pm 5.2$ \\
\hline & 2013 & $458.8 \pm 0.5$ & - & $432.6 * * \pm 0.3$ & $376.7 \pm 0.2$ & $390.28 \pm 0.3$ & $346.9 \pm 0.4$ & - \\
\hline & 2014 & $446.6 \pm 2.1$ & - & $448.5^{*} \pm 1.2$ & $445.7 \pm 5.1$ & $440.5 \pm 4.5$ & $435.5 \pm 0.8$ & - \\
\hline & average & $411.3 \pm 36.6$ & $388.2 \pm 6.7$ & $417.8 \pm 20.7$ & $426.8^{*} \pm 22.6$ & $414.5 \pm 13.2$ & $389.5 \pm 22.8$ & $406.4 \pm 5.2$ \\
\hline \multirow{4}{*}{$\begin{array}{l}\text { Oil yield } \\
\mathrm{kg} \mathrm{ha}^{-1}\end{array}$} & 2012 & $571.8 \pm 2.3$ & $803.7 \pm 13.9$ & $822.8 \pm 13.4$ & $966.5 \pm 9.8$ & $907.9 \pm 8.6$ & $930.6 \pm 15.5$ & $991.7 * \pm 12.9$ \\
\hline & 2013 & $821.3 \pm 0.9$ & - & $869.5 \pm 0.6$ & $824.9 \pm 0.5$ & $878.1^{*} \pm 0.7$ & $763.3 \pm 0.9$ & - \\
\hline & 2014 & $1104.8 \pm 5.1$ & - & $1116.7 \pm 3.0$ & $1120.1^{*} \pm 12.8$ & $1040.3 \pm 10.8$ & $1087 \pm 2.1$ & - \\
\hline & average & $832.6 \pm 135.9$ & $803.7 \pm 13.9$ & $936.3 \pm 80.8$ & $970.5^{*} \pm 75.6$ & $942.1 \pm 44.5$ & $927.2 \pm 83.1$ & $991.7 \pm 12.9$ \\
\hline
\end{tabular}

\footnotetext{
* - the highest positive difference compared with the control; (values are mean \pm standard deviation (SD), $P<0.05$ )
} 
from $-6 \%$ to $+4 \%$ in comparison with the control sample. The highest oil content was obtained in the $75 \mathrm{mg} \mathrm{l}^{-1}$ of NPNDT treatment. The increase of oil content was positively correlated with the increase of rapeseed yield $(P<0.05)$ in the treatments sprayed with $50 \mathrm{mg} \mathrm{l}^{-1}$ concentration of NPNDT. Oil yield varied from $+11 \%$ to $+17 \%$ compared with the control treatment. Several authors have shown the influence of N-(4-methoxy2 -nitrophenyl)- $\beta$-alanine sodium salt $(380 \mu \mathrm{M})$ on rapeseed and demonstrated that the yield varied from $-7 \%$ to $+13 \%$ (Braziene et al., 2012) and 1000 seed weight increased to $+9.4 \%$, and the yield to $+10.8 \%$ compared with the control treatment (Žiaukienè et al., 2010). According to Braziene et al. (2012), plant growth regulating effects of $\beta$-alanine derivative can be linked to its osmolytic characteristics. Good results were shown by $N$-(4-methoxy-2-nitrophenyl)- $\beta$-alanine sodium salt $(380 \mu \mathrm{M})$ together with the micronutrient fertilizers ARVI micro, the rapeseed yield, as compared with the control, significantly increased by $15.2 \%$. Miliuviene and Novickiene (2004) have shown that the influence of analogues of dimethylmorpholinium chloride 17-DMC increased seed number, 1000 seed weight and yield. This compound (17-DMC) is supposed to influence growth by changing the content of phytohormones, mainly IAA and $\mathrm{GA}_{3}$. The compound tested in the current study may have similar properties.

Reaserch conducted in Germany with winter oilseed rape sprayed with triazole fungicides Harvesan (a.i. flusilazole $250 \mathrm{~g} \mathrm{l}^{-1}+$ carbendazim $125 \mathrm{~g} \mathrm{l}^{-1}$ ) and Folicur (a.i. tebuconazole $250 \mathrm{~g} \mathrm{l}^{-1}$ ) reported that oil content in rapeseed significantly increased after triazole application compared with the control. The application of fungicides Ortiva (a.i. azoxystrobin $250 \mathrm{~g} \mathrm{l}^{-1}$ ) and Cantus (a.i. boscalid $500 \mathrm{~g} \mathrm{~kg}^{-1}$ ) in combination with triazole fungicides enhanced oil content by extending the seed formation phase which led to increased oil accumulation in the seeds. Inclusion of the fungicide Caramba (a.i. metconazole $8.6 \%$ ) improved the yield-associated parameters (the number of siliques and the seeds per main stem) and seed yield, and also resulted in higher oil content (Ijaz et al., 2015).

The effect of NPNDT on the protein content, ash, flavonoids and DPPH radical scavenging in rapeseed is presented in Table 4.

The application of NPNDT increased protein

Table 4. Effect of different NPNDT concentrations on the composition of rapeseed

\begin{tabular}{|c|c|c|c|c|c|c|c|c|}
\hline \multirow{2}{*}{$\begin{array}{l}\text { Rapeseed } \\
\text { composition }\end{array}$} & \multirow[t]{2}{*}{ Year } & \multicolumn{7}{|c|}{$\begin{array}{l}\text { NPNDT concentration } \\
\mathrm{mg} \mathrm{l}^{-1}\end{array}$} \\
\hline & & 0 (control) & 25 & 50 & 75 & 100 & 125 & 150 \\
\hline \multirow{4}{*}{$\begin{array}{l}\text { Protein } \\
\text { content } \\
\mathrm{g} 100 \mathrm{~g}^{-1}\end{array}$} & 2012 & $15.9 \pm 0.03$ & $27.1 \pm 0.10$ & $30.7 \pm 0.10$ & $31.2 * \pm 0.01$ & $30.3 \pm 0.01$ & $22.8 \pm 0.01$ & $22.5 \pm 0.17$ \\
\hline & 2013 & $29.4 \pm 0.37$ & - & $21.4 \pm 0.37$ & $26.4 \pm 0.37$ & $21.8 \pm 0.30$ & $16.1 \pm 0.27$ & - \\
\hline & 2014 & $14.1 \pm 0.17$ & - & $16.7 \pm 0.23$ & $20.3^{*} \pm 0.03$ & $18.9 \pm 0.07$ & $15.8 \pm 0.10$ & - \\
\hline & average & $19.8 \pm 2.43$ & $27.1 \pm 0.10$ & $22.9 \pm 2.10$ & $26.0 * \pm 1.60$ & $23.7 \pm 1.73$ & $18.2 \pm 1.17$ & $22.5 \pm 0.17$ \\
\hline \multirow{4}{*}{$\begin{array}{c}\text { Ash } \\
\%\end{array}$} & 2012 & $4.5 \pm 0.00$ & $4.5 \pm 0.03$ & $4.5 \pm 0.03$ & $4.2 \pm 0.03$ & $4.2 \pm 0.03$ & $4.1 \pm 0.03$ & $4.1 \pm 0.03$ \\
\hline & 2013 & $3.1=$ & - & $3.8^{*} \pm 0.07$ & $3.4 \pm 0.04$ & $3.6 \pm$ & $3.5 \pm$ & - \\
\hline & 2014 & 4.1 & - & $3.6 \pm 0.23$ & $3.5 \pm 0.14$ & $3.3 \pm$ & $3.2 \pm$ & - \\
\hline & average & 3.90 & $4.5 \pm 0.03$ & $4.0 * \pm 0.17$ & $3.7 \pm 0.20$ & $3.7 \pm 0.20$ & $3.6 \pm 0.14$ & $4.1 \pm 0.03$ \\
\hline \multirow{4}{*}{$\begin{array}{l}\text { Flavonoids } \\
\mathrm{mg} \mathrm{g}^{-1}\end{array}$} & 2012 & $0.31 \pm 0.003$ & - & $0.3 \pm 0.003$ & $0.31 \pm 0.003$ & $0.43 \pm 0.003$ & $0.44 \pm 0.003$ & $0.45^{*} \pm 0.003$ \\
\hline & 2013 & $0.45=$ & - & $0.38 \pm 0.001$ & $0.42 \pm 0.000$ & $0.43 \pm 0.000$ & $0.45^{*} \pm 0.003$ & - \\
\hline & 2014 & $0.37 \pm$ & - & $0.30 \pm 0.010$ & $0.26 \pm 0.003$ & $0.35 \pm 0.003$ & $0.28 \pm 0.007$ & - \\
\hline & average & $0.38 \pm 0.02$ & - & $0.33 \pm 0.013$ & $0.33 \pm 0.023$ & $0.41 \pm 0.013$ & $0.42 * \pm 0.013$ & $0.45 \pm 0.003$ \\
\hline & 2012 & $49.8 \pm 3.44$ & $52.0 \pm 1.16$ & $61.1 \pm 1.40$ & $67.4^{*} \pm 0.36$ & $60.4 \pm 0.68$ & $61.4 \pm 2.76$ & $65.9 \pm 1.96$ \\
\hline & 2013 & $78.8 \pm 0.08$ & - & $79.6^{*} \pm 2.48$ & $77.3 \pm 2.52$ & $76.9 \pm 0.68$ & $72.9 \pm 0.24$ & - \\
\hline scaver & 2014 & $43.7 \pm 0.04$ & - & $47.8 \pm 0.04$ & $42.9 \pm 0.04$ & $49.1 * \pm 0.08$ & $44.6 \pm 0.00$ & - \\
\hline$\%$ & average & $58.7 \pm 6.76$ & $52.0 \pm 1.16$ & $62.7 \pm 5.40$ & $63.0 * \pm 5.92$ & $61.9 \pm 4.60$ & $59.8 \pm 4.92$ & $65.9 \pm 1.96$ \\
\hline
\end{tabular}

* - the highest positive difference in comparison with the control

content in the first experimental year from 15.9 to $31.2 \mathrm{~g}$

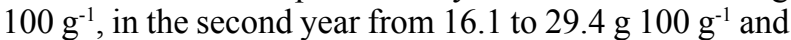

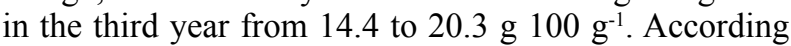
to the average data of $2012-2014$, the highest protein

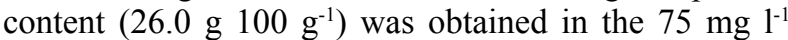
NPNDT treatments in all experimental years. The protein content increased by $+31 \%$ compared with the control treatment. This increase was statistically significant $(P<0.05)$. Studies of other researchers (Braziene et al., 2012) showed that the influence of $N$-(4-methoxy-2nitrophenyl)- $\beta$-alanine sodium salt $(380 \mu \mathrm{M})$ on rapeseed protein content varied from $0 \%$ to $+3 \%$ compared with the control.

With the application of NPNDT, ash content varied from $4.5 \%$ to $4.1 \%$ in the first experimental year, from $3.8 \%$ to $3.1 \%$ in the second year and $3.2 \%$ to $4.1 \%$ in the third year. The lowest ash content ( $4.1 \%$ and $3.2 \%)$ was recorded in the treatments sprayed with $125 \mathrm{mg} \mathrm{l}^{-1}$ of NPNDT in the first and in the third year, and it was 3.1\% in the control treatment in the second year. According to the average data of 2012-2014, the lowest ash content was determined in the $125 \mathrm{mg} \mathrm{l}^{-1}$ NPNDT treatment.

In all seed samples in the first experimental year, the antioxidant activity was higher than in the control treatment. In the second year, the antioxidant activity in the seeds varied insignificantly. In the third year, the antioxidant activity in seeds varied from $42.9 \%$ to $49.1 \%$. Summarizing three experimental years, the highest average antioxidant activity was obtained in rapeseed in the $75 \mathrm{mg} \mathrm{l}^{-1}$ NPNDT treatment.

Antioxidants include such compounds as flavonoids, ascorbic acid, carotenoids and other. The content of flavonoids in rapeseed was measured. The highest content of flavonoids $\left(0.45 \mathrm{mg} \mathrm{g}^{-1}\right)$ was determined in the $150 \mathrm{mg} \mathrm{l}^{-1}$ NPNDT treatment in the first experimental year; it was 0.45 and $0.38 \mathrm{mg} \mathrm{g}^{-1}$ in the 125 $\mathrm{mg} \mathrm{l}^{-1}$ NPNDT in the second and third year, respectively. According to the average data of three years, flavonoid content varied from $-13 \%$ to $+18 \%$ compared with the controltreatment. The increase in flavonoid content was 
positively correlated with an increase in DPPH radical scavenging $(P<0.05)$.

Fatty acids were determined by gas chromatography. The effect of NPNDT on the composition of fatty acids in rapeseed is presented in Table 5.

In the first experimental year, the oleic acid content changed insignificantly and varied from $-0.09 \%$ to $+0.77 \%$ compared with the control treatment. In the $50 \mathrm{mg} \mathrm{l}^{-1}$ NPNDT treatment, the seeds contained the highest oleic acid content $(61.5 \%)$. In the second year, oleic acid content in rapeseed was slightly lower than or equal to that in the control sample. In the third

Table 5. Effect of different NPNDT concentrations on the content of fatty acids in rapeseed oil

\begin{tabular}{|c|c|c|c|c|c|c|c|c|}
\hline \multirow{2}{*}{$\begin{array}{c}\text { Composition of } \\
\text { fatty acids in } \\
\%\end{array}$} & \multirow[t]{2}{*}{ Year } & \multicolumn{7}{|c|}{$\begin{array}{l}\text { NPNDT concentration } \\
\mathrm{mg} \mathrm{l}^{-1}\end{array}$} \\
\hline & & 0 (control) & 25 & 50 & 75 & 100 & 125 & 150 \\
\hline \multirow{4}{*}{ Palmitic } & 2012 & $5.1 \pm 0.1$ & $4.6 \pm 0.1$ & $4.8 \pm 0.1$ & $4.6 \pm 0.1$ & $5.2 \pm 0.2$ & $4.9 \pm 0.1$ & $4.8 \pm 0.0$ \\
\hline & 2013 & $3.8 \pm 0.1$ & - & $3.7 \pm 0.1$ & $3.6 \pm 0.0$ & $3.8 \pm 0.1$ & $3.8 \pm 0.2$ & - \\
\hline & 2014 & $4.5 \pm 0.1$ & - & $4.6 \pm 0.1$ & $4.6 \pm 0.1$ & $4.7 \pm 0.0$ & $4.6 \pm 0.1$ & - \\
\hline & average & $4.5 \pm 0.3$ & $4.6 \pm 0.1$ & $4.2 \pm 0.3$ & $4.3 \pm 0.3$ & $4.6 \pm 0.4$ & $4.4 \pm 0.3$ & $4.8 \pm 0.0$ \\
\hline \multirow{4}{*}{ Stearic } & 2012 & $2.1 \pm 0.1$ & $2.0 \pm 0.0$ & $2.1 \pm 0.0$ & $2.0 \pm 0.0$ & $2.1 \pm 0.0$ & $2.0 \pm 0.0$ & $2.0 \pm 0.0$ \\
\hline & 2013 & $1.7 \pm 0.1$ & - & $1.6 \pm 0.1$ & $1.6 \pm 0.1$ & $1.6 \pm 0.1$ & $1.6 \pm 0.0$ & - \\
\hline & 2014 & $1.9 \pm 0.1$ & - & $1.9 \pm 0.1$ & $2.0 \pm 0.1$ & $2.1 \pm 0.0$ & $2.0 \pm 0.0$ & - \\
\hline & average & $1.9 \pm 0.1$ & $2.0 \pm 0.0$ & $1.8 \pm 0.1$ & $1.9 \pm 0.1$ & $1.9 \pm 0.2$ & $1.9 \pm 0.1$ & $2.0 \pm 0.0$ \\
\hline \multirow{4}{*}{ Oleic } & 2012 & $61.0 \pm 0.2$ & $61.1 \pm 0.1$ & $61.5 \pm 0.0$ & $61.3 \pm 0.0$ & $60.9 \pm 0.1$ & $61.2 \pm 0.1$ & $61.4 \pm 0.0$ \\
\hline & 2013 & $65.4 \pm 0.1$ & - & $65.2 \pm 0.1$ & $65.4 \pm 0.1$ & $65.3 \pm 0.2$ & $65.4 \pm 0.1$ & - \\
\hline & 2014 & $63.2 \pm 0.1$ & - & $62.8 \pm 0.1$ & $63.1 \pm 0.1$ & $63.4 \pm 0.1$ & $63.6 \pm 0.1$ & - \\
\hline & average & $63.2 \pm 1.1$ & $61.1 \pm 0.1$ & $63.4 \pm 0.9$ & $63.3 \pm 1.0$ & $63.2 \pm 1.0$ & $63.4 \pm 1.0$ & $61.4 \pm 0.0$ \\
\hline \multirow{4}{*}{ Linoleic } & 2012 & $20.6 \pm 0.1$ & $20.8 \pm 0.1$ & $20.6 \pm 0.0$ & $20.9 \pm 0.1$ & $20.9 \pm 0.0$ & $20.8 \pm 0.1$ & $20.9 \pm 0.1$ \\
\hline & 2013 & $18.0 \pm 0.0$ & - & $18.3 \pm 0.1$ & $18.1 \pm 0.1$ & $18.3 \pm 0.0$ & $18.2 \pm 0.1$ & - \\
\hline & 2014 & $20.3 \pm 0.1$ & - & $20.0 \pm 0.1$ & $20.4 \pm 0.1$ & $20.1 \pm 0.0$ & $20.0 \pm 0.1$ & - \\
\hline & average & $19.6 \pm 0.6$ & $20.8 \pm 0.1$ & $19.4 \pm 0.6$ & $19.8 \pm 0.8$ & $19.8 \pm 0.6$ & $19.7 \pm 0.6$ & $20.9 \pm 0.1$ \\
\hline \multirow{4}{*}{ Eicosenoic } & 2012 & $1.0 \pm 0.1$ & $1.1 \pm 0.0$ & $1.1 \pm 0.0$ & $1.1 \pm 0.0$ & $0.9 \pm 0.1$ & $1.0 \pm 0.0$ & $1.0 \pm 0.0$ \\
\hline & 2013 & $1.2 \pm 0.0$ & - & $1.2 \pm 0.1$ & $1.2 \pm 0.0$ & $1.1 \pm 0.1$ & $1.1 \pm 0.0$ & - \\
\hline & 2014 & $1.2 \pm 0.1$ & - & $1.1 \pm 0.0$ & $1.1 \pm 0.1$ & $1.1 \pm 0.1$ & $1.1 \pm 0.1$ & - \\
\hline & average & $1.1 \pm 0.1$ & $1.1 \pm 0.0$ & $1.1 \pm 0.1$ & $1.1 \pm 0.1$ & $1.1 \pm 0.1$ & $1.1 \pm 0.0$ & $1.0 \pm 0.0$ \\
\hline \multirow{4}{*}{ Linolenic } & 2012 & $8.5 \pm 0.0$ & $8.8 \pm 0.0$ & $8.5 \pm 0.0$ & $8.7 \pm 0.0$ & $8.7 \pm 0.0$ & $8.6 \pm 0.0$ & $8.6 \pm 0.0$ \\
\hline & 2013 & $8.1 \pm 0.1$ & - & $8.2 \pm 0.1$ & $8.2 \pm 0.1$ & $8.2 \pm 0.0$ & $8.2 \pm 0.1$ & - \\
\hline & 2014 & $6.8 \pm 0.1$ & - & $6.7 \pm 0.1$ & $6.9 \pm 0.1$ & $6.8 \pm 0.1$ & $6.3 \pm 0.1$ & - \\
\hline & average & $7.8 \pm 0.4$ & $8.8 \pm 0.0$ & $8.4 \pm 0.5$ & $7.9 \pm 0.5$ & $7.9 \pm 0.5$ & $7.7 \pm 0.6$ & $8.6 \pm 0.0$ \\
\hline
\end{tabular}

Note. Values are mean \pm standard deviation (SD), $P<0.01$.

year, the oleic acid content changed insignificantly and varied from $-0.6 \%$ to $+0.6 \%$ compared with the control sample. In 2012-2014, the highest oleic acid content was determined in the 50 and $125 \mathrm{mg} \mathrm{l}^{-1}$ NPNDT treatments.

With the application of NPNDT, the content of linoleic acid in rapeseed oil in the first year of research slightly increased and remained unchanged in the second and third years. The highest content of linoleic acid $(20.9 \%)$ was determined in the $75 \mathrm{mg} \mathrm{l}^{-1}$ NPNDT treatment in the first year; it was $18.3 \%$ in the $50 \mathrm{mg} \mathrm{l}^{-1}$ NPNDT treatment in the second year and $2.5 \%$ in the $75 \mathrm{mg} \mathrm{l}^{-1}$ NPNDT treatment in the third year.

According to the averaged data of three years, the content of palmitic and stearic fatty acids in rapeseed oil changed insignificantly compared with the control treatment. Other researchers obtained similar data in the experiments with other $\beta$-alanine derivatives (Brazienè et al., 2012).

The results of Darginavičienè et al. (2011) demonstrated that Ethephon decreased the content of saturated fatty acids and increased the monounsaturated fatty acid levels in cv. 'SW Landmark'. The only observed change was the increase of the amount of linolic acid. In our study, the seeds of cv. 'SW Landmark' contained about $2 \%$ more oleic acid and about $2 \%$ less linolenic acid compared with Darginavičienè et al. (2011) findings.

Three primers (P-01, P-02 and P-03) used in the analysis with spring oilseed rape cv. 'SW Landmark' produced 16 polymorphic amplification products. Amplification size ranged from 250 up to $1200 \mathrm{bp}$
(Table 1). Each primer generated 4 to 8 individual bands per primer and provided a distinct and reproducible pattern of the amplified PCR fragments (Fig.). The most informative primer was $\mathrm{P}-01$.

The results showed that in the leaf samples sprayed with $125 \mathrm{mg} \mathrm{l}^{-1}$ NPNDT, the DNA was intact compared with the DNA of the control samples $(\mathrm{C} 1, \mathrm{C} 2$ and $\mathrm{C} 3$ ).

The main observation from these experiments is that NPNDT could be used as a possible growth regulator for increasing the yield of rapeseed. The further research of this compound will exhibit which stress resistance it will increase in plants. A wide range of metabolites have been identified, including mono, di-, oligo- and polysaccharides such as glucose, fructose, sucrose, trehalose, raffinose, and fructans; amino acids such as proline, pipecolic acid; methylated proline-related compounds such as methyl-proline, proline betaine, and hydroxyproline betaine; sugar alcohols (polyols) such as sorbitol, mannitol, glycerol, inositol, and methylated inositols; other betaines, such as glycine betaine, $\beta$-alanine betaine, choline $O$-sulfate, and tertiary sulphonium compounds such as dimethylsulphoniopropionate (DMSP), in halophytes in response to salinity. Analogy to organic acids up and down regulation, the quaternary ammonium compounds also accumulate in plants subjected to salt stress. These include glycinebetaine, $\beta$-alanine betaine, proline betaine, choline $O$-sulfate, hydroxyproline betaine, and pipecolate betaine. Besides glycinebetaine, $\beta$-alanine betaine also 


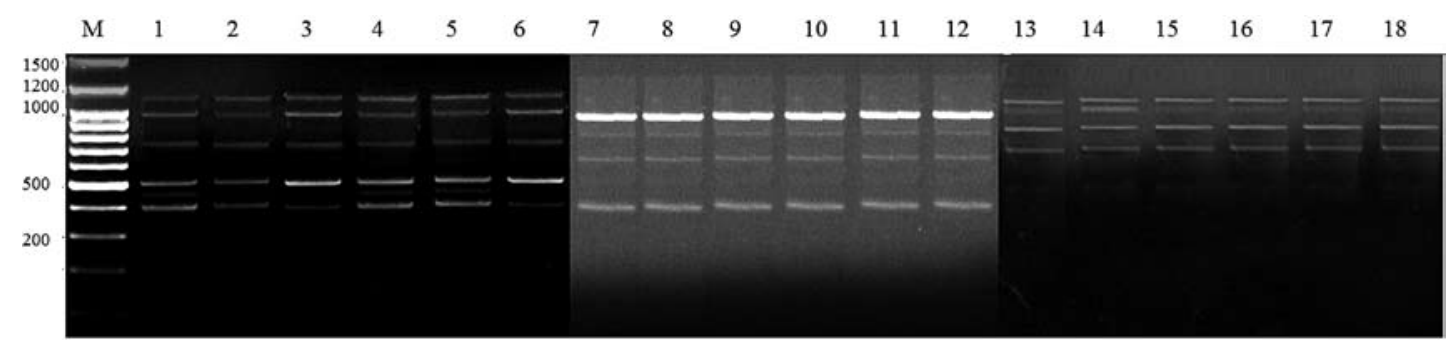

Lane 1-3, 7-9, 13-15 are C1-C3 samples, lane 4-6, 10-12, 16-17 affected samples (S1-S3); M-Gene Ruler 100 bp DNA Ladder Plus (Thermo Fisher Scientific, Lithuania)

Figure. DNA fragments from samples of oilseed rape leaves obtained by PCR with primers: P-01 (lane 1-6), P-02 (lane 7-12) and P-03 (lane 13-18)

acts as an osmoprotectant in saline conditions (Kumari et al., 2015). Our compound has a $\beta$-alanine fragment in its structure, and it could affect plant resistance when salinity is increasing. The $\beta$-alanine derivative could be used for the reinforcement of plants under the N/C imbalance. Studies of other researchers (Schwarz et al., 2014) from Germany showed that many metabolites of the $\mathrm{N}$ metabolism such as ornithine, arginine, $\beta$-alanine, and aspartate show a pattern that gives a clear indication for the $\mathrm{N} / \mathrm{C}$ imbalance.

\section{Conclusions}

1. The research showed that $125 \mathrm{mg}^{-1}$ of $N$-phenyl- $N$-(5-oxo-4,5-dihydro-1,3-thiazol-2-yl)- $\beta$ alanine sodium salt (NPNDT) had the greatest influence on spring oilseed rape plant growth. The highest number of secondary branches $(6.0 \pm 2.2$ branches per plant $)$ $(P<0.05)$, the lowest plant height $(121.4 \pm 5.7 \mathrm{~cm})$ $(P<0.05)$ and the highest rapeseed yield $\left(2.4 \pm 0.2 \mathrm{tha}^{-1}\right)$ $(P<0.05)$ were determined in this treatment. The highest 1000 seed weight and silique length were established in the $50 \mathrm{mg} \mathrm{l}^{-1}$ NPNDT treatment. The highest seed number per pod $(P<0.05)$ was determined in the $75 \mathrm{mg} \mathrm{l}^{-1}$ NPNDT treatment.

2. The NPNDT solution increased oil and protein content in rapeseed. The highest oil $(970.5 \pm$ $\left.128.6 \mathrm{~kg} \mathrm{ha}^{-1}\right)(P<0.05)$ and protein $\left(26.0 \pm 4.8{\left.\mathrm{~g} 100 \mathrm{~g}^{-1}\right)}^{-1}\right.$ $(P<0.05)$ content was obtained in the $75 \mathrm{mg} \mathrm{l}^{-1}$ NPNDT treatment. The tested compound had no significant impact on the chemical composition of rapeseed oil.

3. The highest content of flavonoids was obtained in the treatments sprayed with $125 \mathrm{mg} \mathrm{l}^{-1}$ NPNDT solution. The increase in flavonoid content was positively correlated with the increase in DPPH radical scavenging $(P<0.05)$.

4. The lowest ash content $(3.6 \pm 0.4 \%)$ was recorded in the $75 \mathrm{mg} \mathrm{l}^{-1}$ NPNDT treatment.

5. The $125 \mathrm{mg} \mathrm{l}^{-1}$ concentration of NPNDT solution had no effect on the DNA of spring oilseed rape (Brassica napus L.).

Received 02052016 Accepted 03012017

\section{References}

Abdelmigid H. M. 2012. Efficiency of random amplified polymorphic DNA (RAPD) and inter-simple sequence repeats (ISSR) markers for genotype fingerprinting and genetic diversity studies in canola (Brassica napus). African Journal of Biotechnologv, 11 (24): 6409-6419 https://doi.org/10.5897/ajb11.127

Akoh C. C., Min D. B. 2002. Food lipids. Chemistry, nutrition and biotechnologv. New York. USA. 402 p. https://doi.org/10.1201/9780203908815

Amalesh S., Gounranga D., Sanjoy K. D. 2011. Roles of flavonoids in plants. Journal of Pharmaceutical Science and Technology, 6: 12-35

Baux A., Hebeisen T., Pellet D. 2008. Effects of minimal temperatures on low-linolenic rapeseed oil fatty-acid composition. Furnnean Iournal of Agronomy, 29 (2-3): 102-107 https://doi.org/10.1016/j.eja.2008.04.00'5

Bradford M. M. 1976. A rapid and sensitive for the quantitation of microgram quantities of protein utilizing the principle of protein-dye binding. Analytical Biochemistry. 72: 248-254 https://doi.org/10.1016/0003-2697(76)90527-3

Brazienè Z., Jakienè E., Žiaukienè D., Mickevičius V. 2012. Influence of $N$-(4-methoxy-2-nitrophenyl)- $\beta$-alanine sodium salt on rape (Brassica napus L.) seed yield and its guality. Chemical Technology. 1 (59): 46-53 https://doi.org/10.5755/j01.ct.59.1.1529

Cartea M. E., Francisco M., Soengas P., Velasco P. 2011. Phenolic comnounds in Brassica vegetahles. Molecules, 16: 251-280 https://doi.org/10.3390/molecules16010251

Cegielska-Taras T., Pniewski T. 2011. The use of herbicides in biotech oilseed rape cultivation and in generation of transgenic homozygous plants of winter oilseed rape (Brassica napus L.). Hasaneen M. N. (ed.). Herbicides mechanisms and more of action, chapter 7, p. 125-136

Crozier A., Jaganath I. B., Clifford M. N. 2009. Dietary phenolics: chemistry, bioavailability and effects on health Natural Product Renorts. 26: 1001-1043 https://doi.org/10.1039/b802662a

Darginavičienė J., Novickienė L., Gavelienė V., Jurkonienè S. Kazlauskienè D. 2011. Ethepon and Avertrol as tools to enhanced spring rape productivity. Central European Journal of Biology, 6 (4): 606-615

Edwards K., Johnstone C., Thompson C. 1991. A simple and rapid method of the preparation of plant genomic DNA for PCR analysis. Nucleic Acids Research, 19 (6): 1349 https://doi.org/10.1093/nar/19.6.1349

Gad N. 2010. Improving quantity and quality of canola oil yield through cobalt nutrition. Agriculture and Biology Journal of North America 1 (5): 1090-1097 https://doi.org/10.5251/abjna.2010.1.5.1090.1097

Huberman M., Roiv J., Goldschmidt E. E., Apelbaum A., Goren R. 2014. The novel ethylene antagonist, 3-cyclopropyl-1-enyl-propanoic acid sodium salt (CPAS), increases grain yield in wheat by delaying leaf senescence. Plant Growth Regulation 73. 249-255 https://doi.org/10.1007/s10725-013-9885-5

Ijaz M., Mahmood K., Honermeier B. 2015. Interactive role of fungicides and plant growth regulator (Trinexapac) on seed yield and oil quality of winter raneseed. Agronomy, 5 (3): 435-446 https://doi.org/10.3390/agronomy 5030435

Ion G., Aksinsete J. A., Hardman W. E. 2010. Maternal consumption of canola oil suppressed mammary gland tumorigenesis in C. (1) Tag mice offsnring. BMC Cancer, 10 (81): 1-12 https://doi.org/10.1186/1471-2407-10-81

Jodinskienè M., Paulauskas A., Žukauskienè J. 2008. Investigations of oilseed rape (Brassica napus L.) genetic diversity by molecular methods. Biologija, 54 (4): 238-241 https://doi.org/10.2478/v10054-008-0049-x

Kazlauskienė D., Gavelienè V., Novickienė L. 2008. Control of anthesis and formation of reproductive organs in spring rane (Brassica namus L.). Biologiia, 54 (4): 279-282 https://doi.org/10.2478/v10054-008-0057-x

Kumari A., Das P., Kumar Parida A., Agarwal P. K. 2015. 
Proteomics, metabolomics, and ionomics perspectives of salinity tolerance in halophytes. Frontiers in Plant Sciences, 6: $537 \mathrm{https}: / /$ doi.org/10.3389/fpls.2015.00537

Madhu L. N., Suchetha K. N., Sarojini B. K. 2011. In vitro and in vivo antioxidant property of sulphydryl group containing 1,2,4-triazole derivative. Drug Invention Today, 3 (12): 297-300

Matysiak K., Kaczmarek S. 2013. Effect of chlorocholine chloride and trizoles-tebuconazole and flusilazole on winter oilseed rape (Brassica napus var. oleifera L.) in response to the application term and sowing density. Journal of Plant Protection Research. 53 (1): 79-88 https://doi.org/10.2478/jppr-2013-0012

Miliuvienè L., Novickienè L. 2004. Peculiarities of the effect of dimethylmorpholinium chloride derivative. Biologija, 1: $45-47$

Mohammadi M., Tavakoli A., Saba J. 2014. Effects of foliar application of 6-benzylaminopurine on yield and oil content in two spring safflower (Carthamus tinctorius L.) cultivars. Plant Growth Regulation. 73 (3): 219-226 https://doi.org/10.1007/s10725-013-9882-8

Patočka J. 2010. Beta-amino acid and their natural biologically active derivatives. 2. Derivatives of beta-lysine and betaarginine. Military Medical Science Letters, 79: 50-53

Patočka J. 2011. $\beta$-amino acids ant their natural biologically active derivatives. 5. Derivatives of unusual alicyclic and heterocyclic $\beta$-amino acids. Military Medical Science Letters, 80: 2-11

Pascual-Teresa de S., Moreno D. A., Garcia-Viguera C. 2010. Flavanols and anthocyanins in cardiovascular health: a review of current evidence. International Journal of Molecular Sciences. 11 (4): 1679-1703 https://doi.org/10.3390/ijms11041679

Pietryczuk A., Biziewska I., Imierska M., Czerpak R. 2014.
Influence of traumatic acid on growth and metabolism of Chlorella vulgaris under conditions of salt stress. Plant Growth Regulation. 73 (2): 103-110 https://doi.org/10.1007/s10725-013-9872-x

Schwarz D., Orf I., Kopka J., Hagemann M. 2014. Effects of inorganic carbon limitation on the metabolome of the Synechocystis sp. PCC 6803 mutant defective in $g \ln B$ encoding the central regulator PII of cyanobacterial $\mathrm{C} / \mathrm{N}$ acclimation. Metabolites. 4 (2): 232-247 https://doi.org/10.3390/metabo4020232

Singleton V. L., Orthofer R., Lamuela-Raventos R. M. 1999. Analysis of total phenols and other oxidation substrates and antioxidants by means of Folin-Ciocalteau reagent. Methods in Enzymology, 299: 152-178 https://doi.org/10.1016/S0076-6879(99)99017-1

Ullah F., Bano A., Nosheen A. 2012. Effect of plant growth regulators on growth and oil quality of canola (Brasica napus L.) under drought stress. Pakistan Journal of Botany, 44 (6): 1873-1880

White W. H., Gunyuzlu P. L., Toyn J. H. 2001. Saccharomyces cerevisiae is capable of de novo pantothenic acid biosynthesis involving a novel pathway of $\beta$-alanine production from spermine. The Journal of Biological Chemistrv. 276: 10794-10800 https://doi.org/10.1074/jbc.M009804200

Žiauka J., Kuusiené S., Silininkas M. 2013. Fast growing aspens in the development of a plant micropropagation system based on plant-produced ethylene action. Biomass and Bioenergy. 53: 20-28 https://doi.org/10.1016/j.biombioe.2013.01.005

Žiaukienė D., Brazienė Z., Jakienė E., Mickevičius V. 2010. Influence of $\beta$-alanine derivatives on the growth parameters of non-overwintering oilseed rape (Brassica napus L.) plants. Chemical Technology, 3-4 (56): 11-18

\title{
$\beta$-alanino darinių įtaka vasarinių rapsų derliui ir aliejaus kokybei
}

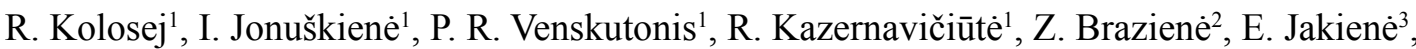 \\ K. Kvederavičiūtét, A. Kanopka ${ }^{4}$, L. Vilys ${ }^{4}$, V. Mickevičius ${ }^{1}$
}

${ }^{1}$ Kauno technologijos universitetas

${ }^{2}$ Lietuvos agrarinių ir miškų mokslų centro Rumokų bandymų stotis

${ }^{3}$ Aleksandro Stulginskio universiteto Žemès ūkio ir maisto mokslų institutas

${ }^{4}$ Vilniaus universiteto Biotechnologijos institutas

\section{Santrauka}

2012-2014 m. Lietuvos agrariniu ir mišku mokslu centro filiale Rumoku bandymų stotyje buvo tirta jivairių koncentracijų $N$-fenil- $N$-(4,5-dihidro-4-okso-2-tiazolil)- $\beta$-alanino natrio druskos (NPNDT) tirpalo įtaka vasariniams rapsams.

Lauko tyrimų duomenys parodè, kad augalų augimui didžiausią įtaką turèjo $125 \mathrm{mg} \mathrm{l}^{-1} \mathrm{NPNDT}$ tirpalas. Panaudojus $125 \mathrm{mg} \mathrm{l}^{-1}$ koncentracijos tirpalą rapsų antrinių šakelių skaičius padidejo iki 6,0 vnt., arba $54 \%$, lyginant su kontroliniu variantu $(P<0,05)$, derlius - iki $2,39 \mathrm{t} \mathrm{ha}^{-1}$, arba $23 \%$, lyginant su kontroliniu variantu $(P<0,05)$. Didžiausias sėklų skaičius ankštaroje $-24,5$ vnt., arba 7,5\% $(P<0,05)$ didesnis nei kontroliniame variante - gautas, kai rapsai buvo nupurkšti $75 \mathrm{mg} \mathrm{l}^{-1}$ koncentracijos NPNDT tirpalu. Didžiausi aliejaus ir baltymu kiekiai gauti, kai rapsai buvo nupurkšti $75 \mathrm{mg} \mathrm{l}^{-1}$ koncentracijos NPNDT tirpalu. Lyginant su kontroliniu variantu, išgaunamo aliejaus kiekis padidejjo $137,9 \mathrm{~kg} \mathrm{ha}^{-1}$, arba $17 \%$, baltymų kiekis - 6,2 g $100 \mathrm{~g}^{-1}$, arba $31 \%$. Rapsų derliaus padidèjimas buvo esminis $(P<0,05)$ visuose laukeliuose, lyginant su kontroliniu variantu. Išgaunamo rapsų aliejaus kiekis teigiamai ir esmingai $(P<0,05)$ koreliavo su rapsų derliaus padidejjimu, kai augalai buvo apipurkšti $50 \mathrm{mg} \mathrm{l}^{-1}$ koncentracijos NPNDT tirpalu. NPNDT turèjo teigiamos itakos aliejaus kokybei - padidèjo baltymu, flavonoidu kiekiai, rapsų sėklose sumažèjo pelenų kiekis, padidejjo DPPH radikalo slopinimas rapsų sẻklų ekstrakte.

Reikšminiai žodžiai: aliejus, $\beta$-alaninų dariniai, Brassica napus, RAPD, sėklų derlius. 